\title{
PROGRAM PEMBELAJARAN TILAWAH AL-QURAN PADA PONDOK PESANTREN AL-QURAN AL-FALAH CICALENGKA BANDUNG \\ (Studi Deskriptif tentang Program Pembelajaran Tilawah Al-Quran Tahun 2015)
}

\author{
Rofik Nursahid, * \\ Aam Abdussalam, Agus Fakhruddin \\ Program Studi Ilmu Pendidikan Agama Islam, \\ Fakultas Pendidikan Ilmu Pengetahuan Sosial, Universitas Pendidikan Indonesia \\ *E-mail : rofik.nursahid@student.upi.edu
}

\begin{abstract}
ABSTRAK
Kitab suci al-Quran merupakan pedoman dan penyelamat kehidupan manusia di dunia. Upaya memahami al-Quran sebagai petunjuk umat manusia di dunia yakni dengan mempelajari al-Quran dan mengajarkan al-Quran. Akan tetapi, umat Islam yang mayoritas di Indonesia tidak lantas membuat seluruh penganutnya mampu membaca al-Quran dengan benar. Kondisi ini justru memprihatinkan dengan terdapatnya umat Islam yang tidak bisa membaca al-Qur'an. Untuk mengatasi kondisi tersebut, peneliti meneliti lembaga pendidikan yang memfokuskan pendidikan di bidang al-Quran yakni Pondok Pesantren Al-Quran AlFalah. Penelitian ini bertujuan untuk mengetahui bagaimana program pembelajaran tilawah al-Quran dengan memfokuskan penelitian kepada perencanaan, proses, dan hasil. Penelitian ini menggunakan desain penelitian studi kasus dengan pendekatan kualitatif. Teknik pengumpulan data yang digunakan adalah wawancara, observasi, dan studi dokumentasi. Dari data tersebut di analisis dengan mereduksi data, display data, dan penarikan kesimpulan. Hasil dari penelitian ini ditemukan data bahwa Pondok Pesantren Al-Quran Al-Falah melaksanakan program pembelajaran tilawah al-Quran dengan 4 tahapan, yang disebut tahapan belajar al-Quran. Tahapan-tahapan tersebut yakni tahajji, mu'allam, murattal dan mujawwad. Kemudian, perencanaan pembelajaran tilawah al-Quran meliputi visi, misi, tujuan, dan rencana kerja. Selanjutnya, pelaksanaan meliputi organisasi program, pelaksanaan kegiatan program, bidang peserta didik, bidang kurikulum dan rencana pembelajaran, bidang pendidik dan tenaga kependidikan, bidang sarana dan prasarana, dan bidang pendanaan. Langkah-langkah pembelajaran tilawah al-Qur'an disesuaikan dengan tahapan belajar alQuran dengan menggunakan metode talaqqī. Ditinjau dari Peraturan Menteri Pendidikan Nasional No. 49 Tahun 2007 tentang Standar Pengelolaan Pendidikan oleh Satuan Pendidikan Nonformal, perencanaan dan pelaksanaan pembelajaran tilawah al-Quran di Pondok Pesantren Al-Quran Al-Falah dikategorikan baik dan cukup baik, serta menghasilkan santri dari serangkaian evaluasi yang memiliki kompetensi membaca al-Quran yang baik, bahkan berprestasi di bidang tilawah al-Quran tingkat Regional, Nasional dan Internasional.
\end{abstract}

Kata Kunci: Pembelajaran, Tilawah, Al-Quran, Pondok Pesantren 


\section{PENDAHULUAN}

Kitab suci al-Quran menjadi pedoman dan penyelamat kehidupan manusia di dunia. Berbeda dengan kitab sebelumnya, al-Quran berlaku untuk semua umat manusia dan berlaku sepanjang zaman. Menurut Hasanuddin (1995, hlm. 1) alQuran merupakan kitab suci umat Islam dan beriman kepadanya tergolong salah satu rukun Iman.

Upaya memahami al-Quran sebagai petunjuk umat manusia di dunia menurut Umar (2008, hlm. 240) yakni dengan mempelajari al-Quran dan mengajarkan alQuran. Hukum mengajarkan al-Quran adalah fard kifāyah. Hadis tentang belajar dan mengajarkan al-Quran yang diriwayatkan oleh Tirmidzi (Al Al Albani, 2007, hlm. 234) adalah "Sebaik-baiknya kamu adalah orang yang belajar al-Quran dan mengajarkannya".

Langkah dasar dalam mempelajari al-Quran, yakni diawali dengan belajar membacanya. Membaca merupakan dasar untuk memulai memahami isi al-Quran. Para ulama, dahulu dan sekarang, menaruh perhatian besar terhadap tilawah (cara membaca) al-Quran sehingga pengucapan lafaz-lafaz al-Quran menjadi baik dan benar.

Kondisi memprihatinkan justru terjadi di masyarakat Islam Indonesia. Faktanya, berdasarkan data di situs website sosbud.kompasiana.com masih banyak yang tidak bisa membaca al-Quran. Menurut Amedz (2013), data hasil survei Institut Ilmu Al-Quran (IIQ) Jakarta menyebutkan bahwa $65 \%$

umat Islam di Indonesia ternyata masih buta aksara al-Quran, 35\%-nya hanya bisa membaca al-Quran saja. Sedangkan yang membaca dengan benar hanya $20 \%$. Umat Islam yang mayoritas tidak lantas membuat seluruh pe-nganutnya mampu memahami ajaran aga-ma Islam dengan baik dan benar.

Pemerintah Indonesia telah berusaha menyelesaikan permasalahan ini. Terdapat berbagai lembaga pendidikan yang menjadikan kompetensi membaca al-Quran menjadi prioritas utama terhadap siswanya. Seperti halnya sekolah umum maupun sekolah dengan sistem pem-belajaran Islam terdapat pembelajaran al-Quran di dalam mata pelajarannya. Lembaga pendidikan harus menangani secara serius masalah masyakarat muslim Indonesia yang belum bisa membaca al-Quran, sehingga dibutuhkan pembelajaran yang efektif dalam perihal pembelajaran al-Quran terutama baca tulis al-Quran.

Di Indonesia telah diselenggarakan lembaga pendidikan baik formal maupun nonformal dalam pendidikan al-Quran seperti madrasah, pesantren dan pengajian di mesjid-mesjid maupun di rumah. Ini menjadi tugas setiap muslim untuk mengajarkan al-Quran kepada muslim yang lainnya. Selain itu, lembaga yang dikhususkan terhadap pembelajaran berlandaskan Islam yakni Pondok Pesantren. Menurut Qomar (2010, hlm. 2) pesantren didefinisikan sebagai suatu tempat pendidikan dan pengajaran yang menekankan pelajaran agama Islam dan didukung asrama sebagai tempat tinggal santri yang bersifat permanen. Maka pesantren kilat atau pesantren ramadhan yang diadakan di sekolah-sekolah umumnya misalnya, tidak termasuk dalam pengertian ini.

Usaha untuk mengupayakan kompetensi seseorang dalam membaca alQuran, yaitu dibutuhkan pembelajaran alQuran yang efektif yang ditangani secara serius dan professional, sehingga di- 
butuhkan kompetensi dalam bidang pembelajaran al-Quran. Tenaga pengajar atau guru harus lebih menguasai pembelajaran membaca al-Quran untuk diajarkan ke-pada siswanya, sehingga siswanya mudah memahami dan menguasai baca tulis alQuran.

Di Bandung terdapat salah satu pondok pesantren al-Quran, yakni Pondok Pesantren Al-Quran Al-Falah Cicalengka Bandung. Pondok pesantren ini mengkhususkan pada pembelajaran al-Quran baik tilawah al-Quran maupun Tahfiz AlQuran.

Berdasarkan latar belakang tersebut maka peneliti tertarik untuk mengetahui bagaimana program pembelajaran al-Quran di Pondok Pesantren Al-Quran Al-Falah. Untuk itu peneliti mengambil judul penelitian "Program Pembelajaran Tilawah Al-Quran Pada Pondok Pesantren AlQur'an Al-Falah I Cicalengka Bandung (Studi Deskriptif tentang Program Pembelajaran Tilawah Al-Quran Tahun 2015)". Hal ini dimaksudkan untuk menjadi salah satu alternatif dalam pembelajaran tilawah al-Quran.

Pembelajaran didefinisikan secara bahasa dan istilah. Menurut Arifin (2013, hlm. 10) secara bahasa kata dasar "pembelajaran" adalah belajar. Istilah "pembelajaran" (instruction) berbeda dengan istilah "pengajaran" (teaching). Kata "pengajaran" lebih bersifat formal dan hanya ada di dalam konteks guru dengan peserta didik di kelas atau sekolah, sedangkan kata "pembelajaran" tidak hanya ada dalam konteks guru dengan peserta didik di kelas secara formal. Akan tetapi, meliputi kegiatan-kegiatan belajar peserta didik di luar kelas yang mungkin saja tidak dihadirkan oleh guru secara fisik. Kata "pembelajaran" lebih menekankan pada kegiatan belajar peserta didik secara sungguh-sungguh yang melibatkan aspek intelektual, emosional, dan sosial, sedangkan kata "pengajaran" lebih cenderung pada kegiatan mengajar di kelas.

Menurut Komalasari (2011, hlm. 34), pembelajaran dapat dipandang dari dua sudut, pertama, pembelajaran dipandang sebagai komponen yang terorganisasi antara lain tujuan pembelajaran, media pembelajaran, materi pembelajaran, stategi dan metode pembelajaran, media pembelajaran/alat peraga, pengorganisasian kelas, evaluasi pembelajaran, dan tindak lanjut pembelajaran (remedial dan penga-yaan). Kedua, pembelajaran dipandang sebagai suatu proses, maka pembelajaran merupakan rangkaian upaya atau kegiatan guru dalam rangka membuat siswa belajar. Proses tersebut meliputi, pertama, Persiapan, dimulai dari merencanakan program pengajaran tahunan, semester, dan penyusunan persiapan mengajar (lesson plan) berikut penyiapan perangkat kelengkapannya, antara lain berupa alat peraga dan alat-alat evaluasi. Persiapan pembelajaran ini juga mencakup kegiatan guru untuk membaca buku-buku atau media cetak lainnya, yang akan disajikannya kepada para siswa dan mengecek jumlah dan keberfungsian alat peraga yang akan digunakan.

Kedua, melaksanakan kegiatan pembelajaran dengan mengacu kepada persiapan pembelajaran yang telah di-buatnya. Pada tahap pelaksanaan pem-belajaran ini, struktur dan situasi pem-belajaran yang diwujudkan guru akan banyak dipengarugi oleh pendekatan atau strategi dan metodemetode pembelajaran yang telah dipilih dan dirancang penerapannya, serta filosofi kerja dan komitmen guru, persepsi, dan sikapnya terhadap siswa.

Ketiga, menindaklanjuti pembelajaran yang telah dikelolanya. Kegiatan 
pascapembelajaran ini dapat berbentuk enrichment (pengayaan), dapat pula berupa pemberian layanan remedial teaching bagi siswa yang berkesulitan belajar.

Selain itu, pembelajaran menurut Sanjaya (2011, hlm. 204) dikatakan sebagai sebagai suatu sistem. Proses pembelajaran terdiri dari beberapa komponen yang satu sama lain saling berinteraksi dan berinterelasi. Komponen-komponen tersebut adalah tujuan, materi pelajaran, metode atau strategi pembelajaran, media dan evaluasi.

Pasal 1 Undang-Undang Republik Indonesia No. 14 Tahun 2005 tentang Guru dan Dosen, menyatakan bahwa guru adalah pendidik professional dengan tugas utama mendidik, mengajar, membimbing, mengarahkan, melatih, menilai, dan mengevaluasi peserta didik pada pendidikan anak usia dini jalur pendidikan formal, pendidikan dasar, dan pendidikan menengah (UndangUndang Guru dan Dosen, 2012, hlm 2).

Adapun dalam Pasal 39 ayat 2 UUSPN No. 20 Tahun 2003 menyatakan bahwa pendidik merupakan tenaga professional yang bertugas merencanakan dan pelaksanaan proses pembelajaran, menilai hasil pembelajaran, melakukan pembimbingan dan pelatihan, serta melakukan penelitian dan pengabdian kepada masyarakat terutama bagi pendidik pada perguruan tinggi (Sagala, 2009, hlm. 195).

Berdasarkan teori sistem pembelajaran tersebut, maka disusunlah pembelajaran yang dimulai dengan perencanaan, pelaksanaan, dan diakhiri dengan evaluasi.

\section{a. Perencanaan}

Perencanaan adalah menyusun langkah-langkah yang akan dilaksanakan untuk mencapai tujuan yang telah ditentukan (Majid, 2012, hlm. 15). Dalam konteks pengajaran, perencanaan dapat diartikan sebagai proses penyusunan materi pelajaran, penggunaan media pengajaran, penggunaan pendekatan dan metode pengajaran, dan penilaian dalam suatu alokasi waktu yang akan dilaksanakan pada masa tertentu untuk mencapai tujuan yang telah ditentukan (Majid, 2012, hlm. 17).

Di dalam Peraturan Menteri Pendidikan Nasional Nomor 49 Tahun 2007 tentang Standar Pengelolaan Pendidikan oleh Satuan Pendidikan Nonformal memaparkan bahwa dalam Perencanaan Program meliputi: pertama, visi satuan pendidikan nonformal. Kedua, misi satuan pendidikan nonformal. Ketiga, tujuan satuan pendidikan nonformal. Keempat, rencana kerja satuan pendidikan nonformal, baik rencana kerja jangka menengah maupun rencana kerja tahunan.

Menurut Percival dan Ellington yang dikutip oleh Uno (2012, hlm. 35) tujuan pembelajaran adalah suatu pernyataan yang jelas dan menunjukkan penampilan atau keterampilan siswa tertentu yang diharapkan dapat dicapai sebagai hasil belajar. Selain itu, tujuan pembelajaran merupakan salah satu aspek yang penting dalam mengembangkan merencanakan pembelajaran. Sebab segala kegiatan pembelajaran muaranya pada tercapainya tujuan tersebut (Uno, 2012, hlm. 34).

\section{b. Pelaksanaan}

Peraturan Menteri Pendidikan Nasional Nomor 49 Tahun 2007 tentang Standar Pengelolaan Pendidikan oleh Satuan Pendidikan Nonformal memaparkan bahwa dalam Pelaksanaan Rencana Kerja meliputi: pertama, pedoman satuan pendidikan nonformal. Kedua, organisasi satuan pendidikan nonformal. Ketiga, pelaksanaan kegiatan satuan pendidikan 
nonformal. Keempat, bidang peserta didik. Kelima, bidang kurikulum dan rencana pembelajaran. Keenam, bidang pendidik dan tenaga kependidikan. Ketujuh, bidang sarana dan prasarana. Kedelapan, bidang pendanaan. Kesembilan, peran serta masyarakat dan kemitraan.

Terdapat dua komponen dalam pelaksanaan pembelajaran, yakni materi pembelajaran dan strategi pembelajaran.

\section{c. Evaluasi}

Evaluasi merupakan sebuah istilah yang telah banyak didefinisikan oleh para ahli. Evaluasi menurut Arifin (2013, hlm. 5) adalah suatu proses yang sistematis dan berkelanjutan untuk menentukan kualitas (nilai dan arti) dari sesuatu, berdasarkan pertimbangan dan kriteria tertentu dalam rangka pembuatan keputusan. Dalam sistem pembelajaran (maksudnya pembelajaran sebagai suatu sistem), evaluasi merupakan salah satu komponen penting dan tahap yang ditempuh oleh guru untuk mengetahui keefektifan pembelajaran (Arifin, 2013, hlm. 2).

Selanjutnya, kata "Tilawah" menurut Sya'bi yang dikutip Romli dan Anwar (2013, hlm. 18) merupakan bentuk mașdar تََلَ - يَتْلُو - تِلاوَةً yang artinya membaca. Sedangkan dalam kamus Al-Munawwir artinya bacaan (Romli \& Anwar, 2013, hlm. 18). Asyafah (Romli \& Anwar, 2013: 18) juga memberikan penjelasan pula mengenai kata tilawah. Bahwa tilawah berarti membacakan atau mengikuti (to follow). Dan jika dihubungkan dengan al-Quran, maka tilawah artinya membacakan ayat-ayat al-Quran, memperdengarkan ayat-ayat al-Quran, membaca dengan mengikuti bacaannya "haqqa tilāwatiћ", atau menyampaikan informasi dan ilmu yang bersumber dari al-Quran.
Jadi dapat disimpulkan tilawah secara bahasa artinya bacaan.

Departemen Pendidikan Nasional (2008, hlm. 1462) juga mendefinisikan tilawah adalah pembacaan (ayat al-Quran) dengan baik dan indah. Selain itu Rouf (2004, hlm. 83) mendefinisikan tilawah adalah membaca al-Quran. Harus ada perbedaan antara membaca al-Quran dan membaca koran atau majalah. Tilawah adalah kegiatan yang aktif dilakukan orang yang beriman kepada al-Quran karena saat itulah otak, lidah, dan hati aktif menyatu untuk merenungi al-Quran.

Para ulama sepakat bahwa hukum mempelajari bacaan al-Quran adalah fard 'ain (kewajiban individual). Seseorang akan dipandang lalai jika sepanjang usianya tidak pernah belajar al-Quran dan membiarkan dirinya buta aksara al-Quran. Sedangkan hukum mengajarkan membaca al-Quran adalah fard kifāyah (kewajiban kolektif), artinya jika dalam satu kelompok masyarakat masih terdapat lembaga atau orang yang mengajarkan Al-Quran maka gugurlah kewajiban itu (Nur, 2012, hlm. 18).

Terdapat banyak metode dalam belajar al-Quran. Metode belajar al-Quran pada umumnya adalah talaqqī. Talaqqī adalah metode pengajaran al-Quran yang diterapkan Rasulullah Saw. dengan seorang guru dan seorang murid yang berinteraksi secara langsung dan ada proses koreksi dan menyimak dalam metode itu (Rouf, 2004, hlm. 84).

Metode lainnya, yakni metode sorogan. Metode sorogan adalah suatu metode yang ditempuh dengan cara guru menyampaikan pelajaran kepada santri secara individual. Penyampaian pelajaran kepada santri secara bergilir ini biasanya dipraktikkan pada santri yang jumlahnya sedikit. Di pesantren, sasaran metode ini 
adalah kelompok santri pada tingkat rendah yaitu mereka yang baru menguasai pembacaan al-Quran (Qomar, 2010, hlm. 142).

Metode pembelajaran tilawah alQuran lainnya yang berkembang sekarang ini, yaitu metode asyarah, metode iqra', metode bil hikmah, dan metode BBQ 99.

\section{METODE}

Dalam penelitian ini, peneliti menggunakan desain penelitian studi kasus. Studi kasus (case study) merupakan suatu penelitian yang dilakukan terhadap kesatuan sistem. Kesatuan ini dapar berupa program, kegiatan, peristiwa, atau sekelompok individu yang terikat oleh tempat, waktu atau ikatan tertentu. Studi kasus adalah suatu penelitian yang diarahkan untuk menghimpun data, mengambil makna, memperoleh pemahaman dari kasus tersebut. (Sukmadinata, 2013, hlm. 64)

Dalam desain ini, peneliti menggunakan pendekatan kualitatif. Menurut Sukmadinata (2013, hlm. 60) Penelitian kualitatif adalah suatu penelitian yang ditujukan untuk mendeskripsikan dan menganalisis fenomena, peristiwa aktivitas sosial, sikap, kepercayaan, persepsi, pemikiran orang secara individual maupun kelompok. Beberapa deskripsi digunakan untuk menemukan prinsip-prinsip dan penjelasan yang mengarah pada penyimpulan. Penelitian kualitatif bersifat induktif: peneliti membiarkan perma-salahapermasalahan muncul dari data atau dibiarkan terbuka untuk interpretasi. Data dihimpun dengan pengamatan yang seksama, mencakup deskripsi dalam konteks yang mendetil disertai catatan-catatan hasil wawancara yang mendalam, serta hasil analisis dokumen dan catatan-catatan.
Partisipan dalam penelitian ini adalah pimpinan Pondok Pesantren AlQuran Al-Falah, penanggung jawab pembelajaran tilawah al-Quran, pengajar tilawah al-Quran dan santri Pondok Pesantren Al-Quran Al-Falah.

Teknik pengumpulan data yang peneliti gunakan diantaranya Wawancara, Observasi dan Studi Dokumentasi. Dari data tersebut dianalisis dengan mereduksi data dengan memilih data yang dibutuhkan serta dikategorikan dengan koding. Data hasil reduksi disajikan dalam display data dengan uraian singkat secara deskriptif dan kemudian disimpulkan.

\section{HASIL DAN PEMBAHASAN}

Pondok Pesantren Al-Quran AlFalah Kabupaten Bandung merupakan Lembaga Pendidikan Agama Islam berada di bawah badan hukum Yayasan Asysyahidiyyah. Yayasan Asysyahidiyyah didirikan atas prakarsa KH. Q. Ahmad Syahid pada tahun 1983 dengan akta tanggal 28 Maret 1983 No. 20 di Jalan Kapten Sangun No. 6 Tenjolaya Cicalengka Bandung Jawa Barat Indonesia dengan tujuan untuk menaungi beberapa lembaga pendidikan dan sosial.

Visi Pondok Pesantren Al-Quran Al-Falah adalah menjadikan Pondok Pesantren Al-Quran Al-Falah sebagai pondok pesantren terdepan dalam men-cetak calon ulama dalam kajian ulum Al-Quran.

Misi Pondok Pesantren Al-Quran Al-Falah adalah mencetak santri untuk menjadi al ulama al 'amilun dan al 'amilun al ulama dengan landasan aqidah ahli al sunnah wa al jama'ah.

Strategi Pondok Pesantren AlQuran Al-Falah adalah membaca, mendalami dan mengamalkan Al-Quran setiap hari. 


\section{a. Perencanaan}

Pembelajaran di Pondok Pesantren Al-Quran Al-Falah menggunakan pengajian kitab salafi. Pengajian kitab salafi adalah program utama bagi semua santri di luar waktu sekolah dengan memadukan konsep tradisional dan metodologi modern. Program ini disajikan agar santri menguasai ajaran Islam secara utuh dari literatur berbahasa arab. Program pengajian ini mencakup studi tilawah, tafsir, hadis, tajwid, aqidah, akhlak, tasawuf, fiqh, bimbingan Ibadah, nahwu, șorof dan bahasa Arab. Dengan program unggulan qira'at dan tahfiz al-Quran yang dipandu oleh para Qari dan Hafiz bertaraf Nasional dan Internasional.

Untuk mencapai visi di atas, dirumuskan tujuan program pembelajaran tilawah al-Quran di Pondok Pesantren AlFalah adalah untuk melestarikan, mempertahankan, menerjemahkan perintah Rasulullah yakni al-Quran sebagai wahyu Allah. Rasulullah mengatakan untuk memperindah al-Quran dengan suaramu, ka-rena al-Quran kelak akan menjadi sya-faat bagi pembacanya, dan prinsipnya tidak lain ibadah karena Allah.

Tujuan program pembelajaran tilawah al-Quran di Pondok Pesantren AlQuran Al-Falah relevan dengan hukum tilawah dan mempelajari al-Quran. Menurut Nur (2012, hlm. 18) hukum mempelajari bacaan al-Quran adalah fard 'ain (kewajiban individual). Seseorang akan dipandang lalai jika sepanjang usianya tidak pernah belajar al-Quran dan membiarkan dirinya buta aksara al-Quran. Sedangkan hukum mengajarkan membaca al-Quran adalah fard kifāyaћ (kewajiban kolektif), artinya jika dalam satu kelompok masyarakat masih terdapat lembaga atau orang yang mengajarkan al-Quran maka gugurlah kewajiban itu.
Kemudian Pondok Pesantren AlQuran Al-Falah untuk mencapai tujuan tersebut menyusun perencanaan. Hal ini sejalan dengan pendapat Majid (2012: 15) bahwa perencanaan adalah menyusun langkah-langkah yang akan dilaksanakan untuk mencapai tujuan yang telah ditentukan. Perencanaan pembelajaran tersebut, diantaranya (1) menentukan kelompok pengajian santri, (2) menentukan guru atau pengajar, (3) menyusun jadwal pengajian, (4) menyusun program akhir tahun.

Perencanaan program pembelajaran tilawah al-Quran yang dilaksanakan di Pondok Pesantren Al-Quran Al-Falah bila ditinjau dengan Peraturan Menteri Pendidikan Nasional Nomor 49 Tahun 2007 tentang Standar Perencanaan Program dalam Pengelolaan Pendidikan oleh Satuan Pendidikan Nonformal telah memenuhi standar perencanaan, disebabkan perencanaan program tersebut telah merumuskan dan menetapkan yang meliputi Visi, Misi, Tujuan dan Rencana Kerja. Akan tetapi, dalam rencana kerja, berdasarkan hasil studi dokementasi tidak ditemukan rencana kerja jangka menengah, tetapi hanya ditemukan rencana kerja tahunan. Oleh karena itu, masih terdapat kekurangan dalam perencanaan tersebut.

\section{b. Pelaksanaan}

Sumber daya manusia di Pondok Pesantren Al-Falah I Cicalengka ini terdiri dari warga Madrasah Tsanawiyah, Mahasiswa dan Santri Takhasus. Kemudian di Pondok Pesantren Al-Quran Al-Falah I Cicalengka Bandung terdapat kurang lebih sekitar 675 orang santri. Untuk santri putra 401 orang dan santri putri 274 orang. Sedangkan untuk pengajar terdapat 50 guru tilawah baik putra maupun putri. Untuk siswa Mts (Madrasah Tsanawiyah) diwajibkan untuk mondok atau menetap di 
asrama pesantren, sekaligus sebagai santri Pondok Pesantren Al-Falah Cicalengka. Sedangkan untuk mahasiswa tidak diwajibkan sehingga ada mahasiswa yang tidak mondok/menetap di pesantren.

Pembelajaran tilawah al-Quran di Pondok Pesantren Al-Quran Al-Falah terdapat 4 tahapan, yang disebut dengan tahapan belajar al-Quran. Tahapan-tahapan tersebut diantaranya:

\section{1) Tahajji}

Tahapan ini merupakan tahapan dasar belajar membaca al-Quran dengan cara mengeja huruf perkalimat disertai harakatnya.

\section{2) Mu'allam}

Tahapan ini merupakan tingkatan lebih tinggi dari tahajji, yakni membaca dengan muatan pembelajaran makhraj, sifat huruf dan penekanan kepada ilmu tajwid. Tahapan ini juga merupakan pembenaran hukum membaca huruf dan hukum-hukum lainnya.

\section{3) Murattal}

Tahapan ini merupakan tahapan membaca al-Quran dengan menerapkan unsur seni membaca al-Quran atau nagam (lagu al-Quran), dengan persentase pembelajaran $70 \%$ pembenaran bacaan dengan ilmu tajwid dan 30\% seni lagu al-Quran.

\section{4) Mujawwad}

Tahapan ini merupakan tahapan membaca al-Quran dengan disertai lagu alQuran (nagam) dengan teknik vokal, dan persentasenya $50 \%$ pembenaran ba-caan dengan ilmu tajwid dan 50\% seni baca alQuran. Tahapan ini cenderung tingkat kesalahan dalam membacanya rendah, dan lebih dikenal dengan qirā'at al-Qur 'ān.

Selanjutnya, untuk melaksanakan proses pembelajaran dibutuhkan langkahlangkah pembelajaran. Pembelajaran tilāwah al-Quran dilaksanakan dengan metode talaqqī, dan terbagi ke dalam empat tahapan.

Rouf (2004, hlm. 84) menjelaskan bahwa talaqqi adalah metode pengajaran al-Quran yang diterapkan Rasulullah Saw. dengan seorang guru dan seorang murid yang berinteraksi secara langsung dan ada proses koreksi dan menyimak dalam metode itu.

Langkah-langkah pembelajaran tilawah al-Quran tersebut diantaranya: Pertama, untuk tahapan tahajji langkahlangkahnya, sebagai berikut 1) membuka pengajian dengan do'a, 2) Ustad memanggil santri secara bergantian berdasarkan absensi kehadiran, 3) Santri mengeja al-Quran perkalimat, dan ustad memperhatikan bacaannya, 4) Santri lain memperhatikan al-Qurannya secara individu, dan 5) pengajian ditutup dengan surat al-fätihah dan do'a.

Kedua, untuk tahapan mu'allam, dan murattal langkah-langkahnya, sebagai berikut 1) membuka pengajian dengan do'a, 2) Santri membacakan beberapa surat pendek dari juz 30, 3) Ustad membacakan ayat al-Quran kemudian di ikuti oleh semua santri, 4) ketika sudah mencapai ba-tasan ayat, santri bergantian membacakan alQuran, 5) setelah selesai, ustad me-ngetes tajwid kepada santri secara ber-gantian dari ayat al-Quran yang dibaca, 6) pengajian ditutup dengan surat al-fātihał dan do'a.

Ketiga, untuk tahapan mujawwad langkah-langkahnya, sebagai berikut 1) membuka pengajian dengan do'a, 2) Ustad menyuruh semua santri membuka alQurannya, 3) Ustad membacakan ayat alQuran dengan disertai lagu al-Quran sebagai contoh, 4) Santri mengikuti, dan ustad memberikan petunjuk apabila santri belum bisa mencontohnya, 5) Santri bergantian membacakan al-Quran, dan 6) 
pengajian ditutup dengan surat al-fātihaћ dan do'a.

Untuk materi pembelajaran tilawah al-Quran yakni Ahkām al-tajwìd. Aḥkām al-tajwìd (hukum tajwid) merupakan materi pokok pembelajaran tilawah al-Quran. Selain itu kitab pengajian yang dipergunakan untuk tajwid adalah Hidayaћ al-Sibyān atau Hidayah al-Mustafid, kitab tilawah adalah Muṣhaf Usंman̄̄ dan kitab qira'at adalah Manhaj Qira'at al-Asyarāh. Materi ini juga ditunjang dengan materi lainnya dengan menggunakan rujukan kitab berbahasa Arab.

Pembelajaran tilawah al-Quran di Pondok Pesantren Al-Falah terdiri dari pengajian al-Quran dan pengajian kitab, sehingga kedua pengajian ini menerapkan metode yang berbeda.

Metode pembelajaran al-Quran dalam pengajian al-Quran yang diterapkan di Pondok Pesantren Al-Falah I Cicalengka merupakan metode klasikal yakni talaqqī. Talaqqī adalah metode face to face antara guru dan murid. Metode ini merupakan metode yang dianjurkan dalam mempelajari al-Quran. Dalam praktiknya terbagi ke dalam 2 bentuk, yaitu pertama, Sorogan adalah metode dengan tatap muka satu guru menghadap satu murid. Kedua, Bandongan adalah metode dengan tatap muka satu guru menghadap banyak murid.

Standar pelaksanaan program pembelajaran tilawah al-Quran ditinjau dari Peraturan Menteri Pendidikan Nasional Nomor 49 Tahun 2007 masih belum sesuai standar. Berdasarkan hasil penelitian, tidak terdapat pedoman satuan pendidikan yang mengatur berbagai aspek pengelolaan secara tertulis. Akan tetapi, dilihat dari keseluruhan aspek telah terlaksana dengan baik. Pertama, pondok pesantren telah membuat organisasi pada program pembelajaran tilawah al-Quran dengan jalur koordinasi dari ketua pondok pesantren sampai kepada santri. Kedua, pelaksanaan kegiatan program pembelajaran tilawah alQuran telah disusun dan diterapkan dengan baik. Ketiga, dalam bidang kesis-waan, pondok pesantren telah melaksa-nakan seleksi masuk pesantren untuk mengukur kemampuan membaca al-Quran santri. Keempat, bidang kurikulum dan kegiatan pembelajaran kurang terlaksana dengan baik. Kelima, bidang pendidik dan tenaga kependidikan untuk pembelajaran tilawah masih kekurangan pendidik. Keenam, bidang sarana dan prasarana untuk pembelajaran tilawah al-Quran sudah disediakan.

Pembelajaran tilawah al-Quran yang diterapkan oleh Pondok Pesantren AlQuran Al-Falah dengan menggunakan tahapan belajar al-Quran yang yakni tahajji, mu'allam, murattal, dan mujawwad. Tentunya pembelajaran tersebut memiliki kelebihan dan kekurangan. Kelebihan pembelajaran tilawah al-Quran di Pondok Pesantren Al-Qurān Al-Falah adalah santri lebih fokus untuk belajar alQuran karena terdapat target ketercapaian tiap tahapannya dan penempatan tersebut disesuaikan dengan kemampuan baca alQuran santri (WRA).

Adapun kekurangan pembelajaran tilawah al-Quran di Pondok Pesantren AlQuran Al-Falah adalah pertama, terdapat beberapa santri yang tidak sesuai dengan harapan orang tua seperti contoh apabila santri berada pada tingkatan tahajjī atau mu'allam tetapi orang tua menyuruh qira 'a $\hbar$ al-Quran tentunya santri tersebut belum mampu. Kedua, apabila anak langsung berada pada tahapan mu'allam tanpa melewati tahapan tahajjī sebelumnya tentunya santri tidak memiliki pengalaman dan kemampuan pada tahapan tahajjī. Ketiga, jumlah guru yang banyak 
dikarenakan tahapan yang beragam dan guru tersebut harus pernah belajar dan menguasai tahapan belajar al-Quran. Dan keempat, pengawasan yang kurang terhadap pembelajaran tilawah al-Quran sehingga masih terdapat santri yang belum mencapai target membaca al-Quran pada tahapan belajar (WRA).

\section{c. Hasil}

Untuk mencapai hasil yang diinginkan, Pondok Pesantren Al-Quran Al-Falah menggunakan serangkaian evaluasi untuk menilai hasil dari pembe-lajaran tilawah al-Quran.

Evaluasi yang dilaksanakan oleh pondok pesantren telah dilaksanakan dengan sistematis dan telah memenuhi standar evaluasi. Sebagaimana pendapat Arifin (2013, hlm. 5) mengatakan bahwa evaluasi adalah suatu proses yang sistematis dan berkelanjutan untuk menentukan kualitas (nilai dan arti) dari sesuatu, berdasarkan pertimbangan dan kriteria tertentu dalam rangka pembuatan ke-putusan.

Evaluasi tersebut terbagi ke dalam dua bagian. Pertama, tes lisan. Tes lisan adalah tes baca al-Quran disertai tes ilmu tajwid dan tes wiridan setelah salat subuh dan magrib. Tes ini diuji oleh dewan pengasuh pesantren atau pengurus yang ditunjuk oleh pihak pesantren. Kedua tes tulisan. Tes tulisan adalah tes kitab. Materi yang diujikan adalah materi yang diajarkan kepada santri dari kitab kuning (kitab klasik berbahasa arab). Soal tes tulisan dibuat oleh ustad atau guru pengajian.

Hasil dari ujian menentukan kenaikan kelas atau tahapan pengajian alQuran, berdasarkan indikator atau kriteria kelulusan yang telah ditetapkan oleh pihak Pondok Pesantren Al-Falah. Adapun indikator nilai kelulusan kelompok tilawah yaitu rentang nilai 1-10. Nilai kelulusan untuk tahajji nilainya 5-6, untuk mu'allam nilainya 6-8, untuk murattal nilainya 7-9 sedangkan untuk mujawwad nilainya disesuaikan dengan tes oleh pihak pesan-tren dan disesuaikan dengan santri yang memiliki bakat dalam bidang seni lagu alQuran.

Berdasarkan data hasil dari program pembelajaran tilawah al-Quran, rentang nilai untuk nilai kelulusan dalam pelaksanaan Ujian Akhir Pesantren yaitu 0-100, dengan indikator kelulusan $>50$. Pelaksanaan UAP kelas IX yang berjumlah 181 orang santri, dengan jumlah santri putra 104, dan santri putri 77. Dari nilai keseluruhan, rata-rata nilai kelulusan 60-70. Santri yang lulus berjumlah 172 orang santri.

Selanjutnya, hasil dari program pembelajaran tilawah al-Quran di Pondok Pesantren Al-Quran Al-Falah Bandung berdasarkan hasil observasi lapangan dilihat cukup berhasil dengan adanya prestasi santri maupun alumninya.

\section{KESIMPULAN}

Berdasarkan hasil dan pengolahan data yang telah dipaparkan pada bab sebelumnya, serta hasil analisis pembahasan hasil penelitian, dapat dikemukakan bahwa program pembelajaran tilawah al-Quran di Pondok Pesantren AlQuran Al-Falah dilaksanakan dengan 4 tahapan, yang disebut dengan tahapan belajar al-Quran. Tahapan-tahapan tersebut yakni tahajji, mu'allam, murattal dan mujawwad. Tahapan ini disesuaikan dengan kemampuan membaca al-Quran santri dengan placement test (tes penem-patan) untuk santri baru dan hasil ujian pesantren untuk santri lama. Adapun simpulan lainnya sebagai berikut. 
1. Pondok Pesantren Al-Quran AlFalah Kabupaten Bandung merupakan Lembaga Pendidikan Agama Islam berada di bawah badan hukum Yayasan Asysyahidiyyah. Yayasan Asysyahidiyyah didirikan atas prakarsa KH. Q. Ahmad Syahid pada tahun 1983 dengan akta tanggal 28 Maret 1983 No. 20 di Jalan Kapten Sangun No. 6 Tenjolaya Cicalengka Bandung Jawa Barat Indonesia dengan tujuan untuk menaungi beberapa lembaga pendidikan dan sosial. Pendiri Pondok Pesantren tersebut adalah anak dari pasangan $\mathrm{KH}$. Muhammad Sholeh dan $\mathrm{Hj}$. Rokayyah yang belajar keilmuan dalam bidang al-Quran dan keilmuan lainnya kepada beberapa kiai di pesantren.

2. Perencanaan program pembelajaran tilawah al-Quran di Pondok Pesantren Al-Quran Al-Falah berdasarkan Standar Perencanaan Program dalam Peraturan Menteri Pendidikan Nasional No. 49 Tahun 2007 tentang Standar Pengelolaan Pen-didikan oleh Satuan Pendidikan Nonformal dikategorikan baik. Hal ini didasarkan pada perencanaan program yang telah diru-muskan dan ditetapkan meliputi Visi Pondok Pesantren, Misi Pondok Pesantren, Tujuan program pembelajaran tilawah al-Quran dan Rencana Kerja Pondok Pe-santren Al-Quran AlFalah. Tujuan program pembelajaran tilawah al-Quran-pun relevan dengan hukum Islam tentang mempelajari tilawah alQuran.
3. Pelaksanaan program pembelajaran tilawah al-Quran di Pondok Pesantren Al-Quran Al-Falah berdasarkan Standar Pelaksanaan Program dalam Peraturan Menteri Pen-didikan Nasional No. 49 Tahun 2007 tentang Standar Pengelolaan Pendidikan oleh Satuan Pendidikan Nonformal di-kategorikan cukup baik. Hal ini didasarkan pada beberapa aspek diantaranya, menetapkan organisasi

4. Pondok Pesantren Al-Quran AlFalah, pelaksanaan kegiatan program, bidang peserta didik, bidang ku-rikulum dan rencana pembelajaran, bidang pendidik dan tenaga kependidikan, bidang sarana dan prasarana, dan bidang pendanaan. Aspek lain yang belum terlaksana yaitu menetapkan pedoman yang mengatur berbagai aspek dalam program pem-belajaran tilawah al-Quran secara tertulis. Adapun untuk langkah-langkah pem-belajaran dibedakan dengan tahapan belajar al-Quran seperti dijelaskan pada Bab IV, tetapi tahapan-tahapan tersebut menggunakan metode talaqqi.

5. Hasil program pembelajaran tilawah al-Quran ini diteliti dengan cara observasi dan studi dokumentasi, berdasarkan data pada Bab IV, hasil program tersebut telah ditunjang dengan serangkaian evaluasi yang telah ditetapkan oleh Pondok Pesantren Al-Falah yang meliputi jenis tes, waktu evaluasi, tempat evaluasi, instrumen evaluasi, dan pelaksanaan evaluasi serta dikategorikan baik. Keberhasilan program pembelajaran tilawah alQuran ini bisa dibuktikan dengan 
keikutsertaan santri dan alumni dalam perlombaan tilawah al-Quran atau MTQ (Musabaqah Tilāwah AlQuran) dan berhasil meraih juara baik pada tingkat Regional, Nasional dan Internasional.

\section{REFERENSI}

Al Albani, M. N. (2007). Shahih Sunan AtTirmidzi [3]. (E. Fr, Ed., \& Fakhturazzi, Trans.) Jakarta: Pustaka Azzam.

Amedz, M. (2013, Desember 25). Buta Huruf Al-Qur'an di Indonesia Sungguh Menyedihkan. Retrieved Januari 13, 2015, from kompasiana.com: http://sosbud.kompasiana.com/2013 /12/25/buta-huruf-al-quran-diindonesia-sungguh-menyedihkan619561.html

Arifin, Z. (2013). Evaluasi Pembelajaran: Prinsip, Teknik Prosedur. (P. Latifah, Ed.) Bandung: PT Remaja Rosdakarya.

Hasanuddin. (1995). Perbedaan Qira'at dan Pengaruhnya Terhadap Istinbath Hukum dalam Al-Qur'an. Jakarta: PT RajaGrafindo Persada.

Komalasari, K. (2011). Pembelajaran Kontekstual: Konsep dan Aplikasi. (N. F. Atif, Ed.) Bandung: PT Refika Aditama.

Majid, A. (2012). Perencanaan Pembelajaran: Mengembangkan Standar Kompetensi Guru. (Mukhlis, Ed.) Bandung: PT Remaja Rosdakarya.

Nasional, D. P. (2008). Kamus Besar Bahasa Indonesia Pusat Bahasa (4 ed.). Jakarta: PT Gramedia Pustaka Utama.
Nur, S. (2012). Energi Ilahi Tilawah AlQur'an. (M. I. Santosa, Ed.) Jakarta: Republika Penerbit.

Qomar, M. (2010). Pesantren: Dari Transformasi Metodologi Menuju Demokratisasi Institusi. Jakarta: Penerbit Erlangga.

Romli, U., \& Anwar, S. (2013). Konsep Tilawah Dalam Alquran. Jurnal Pendidikan Agama Islam - Ta'lim, 11.

Rouf, A. A. (2004). Tarbiyah Syakhsiyah Qur'aniyah

(Membangun Kepribadian Qur'ani). Jakarta Timur: Markaz Al Qur'an.

Sagala, S. (2009). Administrasi Pendidikan Kontemporer. Bandung: Alfabeta.

Sanjaya, W. (2011). Kurikulum Dan Pembelajaran: Teori dan Praktik Pengembangan Kurikulum Tingkat Satuan Pendidikan (KTSP). Jakarta: Kencana.

Sukmadinata, N. S. (2013). Metode Penelitian Pendidikan. Bandung: PT Remaja Rosdakarya.

Undang-Undang Guru dan Dosen. (2012). Bandung: Fokusindo Mandiri.

Umar, N. (2008). Ulumul Qur'an :

Mengungkap Makna-Makna

Tersembunyi Al-Quran. Jakarta: AlGhazali Center.

Uno, H. B. (2012). Perencanaan Pembelajaran. Jakarta: PT Bumi Aksara.

Yahya, M. W. (2012). Bil Hikmah (Metode Terpadu) : Cepat Membaca AlQur'an. Bandung: Fakultas Dakwah Unisba. 